\title{
ENTERPRISE SUPPORT POLICY AND TERRITORIAL COHESION: THE CZECH REPUBLIC (2007-2013)
}

\author{
Jiř́ NOVOSÁK*, Oldřich HÁJEK*, Jana NOVOSÁKOVÁ ${ }^{* *}$, Milan LINDNER ${ }^{\star * *}$ \\ *Tomas Bata University in Zlin, Czech Republic \\ **University of St. Cyril and Methodius in Trnava, Slovakia \\ ***Newton College Prague, Czech Republic
}

\begin{abstract}
The intention of this paper is to evaluate whether the spatial distribution of Structural Funds (SF) for enterprise support interventions follows the relevant territorial cohesion objectives specified in the strategic documents of the Czech Republic in the programming period 2007-2013. The evidence provided suggests mixed results. A relatively high SF allocation to the regions, characterized by strong agglomeration economies and a strong entrepreneurial climate, supports the competitiveness objective, particularly for innovation-oriented interventions. Nevertheless, little support is given to the objective of balanced development because socio-economically disadvantaged regions do not receive a higher SF allocation, in particular traditional industrial regions suffering from industrial decline, high unemployment and with a poor entrepreneurial climate. In this regard, the absorption capacity concept is emphasized as being important for explaining the spatial distribution of SF.
\end{abstract}

Key Words: enterprise support policy, territorial cohesion, absorption capacity, structural funds.

\section{Introduction}

A number of studies have demonstrated a positive relationship between new business formation and regional development. It is claimed that new businesses are a source of innovation and of new employment opportunities (Henry et al. 2003, Lee et al. 2004, Qian et al. 2013), also stimulating structural change and strengthening regional competitiveness (Wang 2006). Other studies have emphasized the importance of fast-growing businesses and of the existing stock of SMEs for job creation and regional growth (Audretsch 2004, Stam 2005). Not surprisingly, these arguments have spurred governments to be interested in enterprise support policies.

The theoretical rationale of enterprise support policies is based on market imperfections, arising from information and knowledge asymmetries, from financial constraints, and from a divergence between private and social interests (Henry et al. 2003, Acs et al. 2016). Additionally, Acs and Szerb (2007), Huggins and Williams (2009), and Dolinská and Ambrozová (2015) describe another motivation for employing enterprise support policies, by emphasizing the importance of entrepreneurial climate (culture) for entrepreneurship and SME development. In both these approaches, space is a crucial element of the theory due to the presence of spatial externalities. In this regard, Audretsch (2015) mentions at least four types of spatial externalities: (a) network externalities stemming from social relations in space; (b) spatially embedded tacit knowledge spillovers; (c) information and knowledge externalities arising from firm exits; and (d) externalities based on the demonstration effect of successful entrepreneurs. A location close to their sources is needed to secure access to these types of externalities, resulting in a disadvantage of some - primarily peripheral - regions (Smallbone et al. 2003). 
Traditionally, enterprise support policies have been understood to be a compensation for market imperfections and for a weak entrepreneurial climate (culture). In this case, policy interventions are targeted at regions where the need is greatest. However, what has attracted increasing attention over recent years is an approach that emphasizes the importance of spatial externalities for economic growth and that also prefers policy interventions targeted at regions with high development potential. These considerations may relate to the recent debate on territorial cohesion and on the interplay between balanced development and spatial competitiveness (Servillo 2010, Colomb and Santinha 2014). It is therefore of high political significance, as also indicated by the content analysis of strategic documents of the Czech Republic in the programming period 2007-2013. The territorial cohesion objectives listed in these documents relating to enterprise support policy include both supporting peripheral and supporting core regions. The relationship of the innovation-oriented SMEs and core regions is noteworthy (Table 1).

The focus of this paper is embedded in this discussion and it evaluates the spatial distribution of enterprise support interventions among Czech Republic's micro-regions, taking the territorial cohesion objectives into account. In this regard, what is analysed is the Structural Fund (hereafter referred to as SF) expenditures earmarked for the Convergence and Regional Competitiveness and Employment Objectives in the programming period 2007-2013 and also categorized as enterprise support interventions. Note the crucial importance of SF for financing the enterprise support policy in the Czech Republic in the programming period 2007-2013. The main research aim is to evaluate whether the spatial distribution of SF follows the territorial cohesion objectives specified in the strategic documents of the Czech Republic in the programming period 2007-2013, notably: (1) the competitiveness objective; (2) the objective of balanced development; and (3) the objective of coherence between regional and structural policies (Table 1). Considering these objectives, SF allocation is evaluated for two types of interventions: (a) innovation-oriented interventions; and (b) other enterprise support interventions. Finally, the importance of the absorption capacity concept for explaining the SF allocation is explored. The theoretical framework is introduced in the next section. Subsequently, materials and methods are illustrated and then empirical results presented and discussed. The last section draws the conclusions.

Territorial cohesion objectives relating to enterprise support policy

Table 1 in the strategic documents of the Czech Republic (2007-2013)

\begin{tabular}{|c|c|}
\hline Document & $\begin{array}{c}\text { Territorial cohesion objectives relating to enterprise support } \\
\text { policy }\end{array}$ \\
\hline MRD CR (2006) & $\begin{array}{l}\text { New business formation and growth, and new job creation, in lagging } \\
\text { regions } \\
\text { Entrepreneurial opportunities in rural areas } \\
\text { R\&D development in core regions and in structurally disadvantaged } \\
\text { regions }\end{array}$ \\
\hline MRD CR (2007) & $\begin{array}{l}\text { Entrepreneurial opportunities in backward regions and in rural areas } \\
\text { Emphasis on innovation-oriented SMEs in core regions } \\
\text { Coherence between regional and structural policies }\end{array}$ \\
\hline MIT CR (2006) & $\begin{array}{l}\text { Reduction of regional disparities through SME development } \\
\text { Coherence between regional and structural policies }\end{array}$ \\
\hline
\end{tabular}

\section{Theoretical Framework}

Our analysis is embedded in the theoretical framework of the spatial distribution of public funds. Several factors influencing the spatial distribution of public funds have been suggested in the research literature. One group of studies has concentrated their attention on the political factors 
including election-specific factors (Dellmuth and Stoffel 2012, Schraff 2014, Luca and Rodriguez-Pose 2015) and politically ideological factors (Kemmerling and Bodenstein 2006, Dellmuth 2011). Another group of studies has investigated the impact of socio-economic factors on the spatial distribution of public funds (Crescenzi 2009, Blažek and Macešková 2010, Crescenzi et al. 2015, Novosák et al. 2015). Moreover, Camaioni et al. (2013), and Bonfiglio et al. (2016) have emphasized the importance of spatial interactions for explaining the spatial distribution of public funds.

This paper is interested in exploring the associations between the level of socio-economic disadvantages of regions, understood as being relevant for operating the territorial cohesion objectives as given in Table 1, and also the spatial distribution of public funds among them. The two main approaches may be distinguished in the literature when defining the socioeconomic disadvantages of regions. The first approach is based on selected indicators of socio -economic regional disadvantages relating, among other factors, to human capital, unemployment, industrial structure and infrastructure endowment (Crescenzi 2009, Bouvet and Dall'Erba 2010, Crescenzi et al. 2015, Novosák et al. 2015, Janíček and Vaigel 2016). The second approach is to use socio-economically disadvantaged regions that are mostly defined artificially on the basis of political considerations (Blažek and Macešková 2010, Hájek et al. 2014). The intention of this paper is to apply both approaches.

The findings, concerning the associations between the level of socio-economic disadvantages of regions, and the spatial distribution of public funds among them, are not unanimous, and the findings depend, among other factors, on the spatial level of analysis. Crescenzi (2009), Lolos (2009), and Crescenzi et al. (2015) pointed out a positive association between the level of socio-economic disadvantages of NUTS II regions and the SF allocation among them. However, this association does not hold particularly well for the lower spatial levels. Hence, Blažek and Macešková (2010), Hájek et al. (2014), observed an even spatial pattern of public fund allocation, with limited influence of the level of socio-economic disadvantages of regions. Luca and Rodriguez-Pose (2015) noted more public funds spent in more developed regions. Nevertheless, one drawback of these studies was that the spatial distribution of public funds was not arranged thematically, despite such an arrangement providing more nuanced insights into the issue. This is another intention of this paper, to focus on analysing two specific types of enterprise support interventions: (1) innovation-oriented interventions; and (2) other enterprise support interventions.

A number of studies have associated a lower public fund allocation in less developed regions with their lower absorption capacity. The absorption capacity of regions is commonly defined as the capacity of regions to effectively and efficiently spend public funds (Tatar 2010, latu and Alupului 2011). Moreover, the supply and demand sides of the absorption capacity concept are distinguished. While the former relates to the institutional aspects of public fund management (Popescu 2015), the latter relates to the capacity of local actors to prepare and submit acceptable projects for financing by using public funds (Cace et al. 2009, Duran 2014). In this regard, several possible explanations are provided on why less developed regions may lag behind in their absorption capacity, including: (1) the lack of suitable projects for financing, notably in some thematic areas; (2) the lack of human capital and the lack of funds for cofinancing; and (3) a weak position of less developed regions in negotiating and lobbying. It is noteworthy that Kaufmann and Wagner (2005), and Klímová and Žítek (2015) have emphasized the lower absorption capacity of less developed regions particularly for innovationoriented interventions.

Despite the importance of the absorption capacity concept in arguing about the spatial distribution of public funds, the empirical research of this kind has been limited, particularly including studies that focus on the demand side of the absorption capacity of regions. This paper adds to the existing knowledge, following the recent theoretical approach suggested by 
Review of variables

\begin{tabular}{|c|c|}
\hline Variable & Description \\
\hline $\begin{array}{l}\text { Population density } \\
\text { (DENSITY) }\end{array}$ & $\begin{array}{l}\text { The variable is defined as the number of inhabitants per square } \\
\text { kilometre in } 2007 \text { and it is log-transformed to improve normality. } \\
\text { The Czech Statistical Office (hereafter referred to as CSO only) } \\
\text { was the source of information. Population density is used as a } \\
\text { proxy of agglomeration economies. }\end{array}$ \\
\hline $\begin{array}{l}\text { Patenting activities } \\
\text { (INNOVATION) }\end{array}$ & $\begin{array}{l}\text { The variable is calculated as the number of patents and utility mod- } \\
\text { els per population aged } 15-64 \text { in the years } 2002-2007 \text { and it is log- } \\
\text { transformed to improve normality. Note that twofold weight was } \\
\text { given to patents. The Industrial Property Office (hereafter referred } \\
\text { to as IPO only) was the source of information about patents and } \\
\text { utility models, whilst data about population was taken from the } \\
\text { CSO. The indicator of innovation was included due to the im- } \\
\text { portance of innovations as a means of enhancing regional competi- } \\
\text { tiveness. }\end{array}$ \\
\hline $\begin{array}{l}\text { Tertiary education } \\
\text { (TERTIARY) }\end{array}$ & $\begin{array}{l}\text { The variable is defined as the proportion of inhabitants with tertiary } \\
\text { education for people aged } 15 \text { and over and it is log-transformed to } \\
\text { improve normality. The variable is calculated as the mean of the } \\
\text { years } 2001 \text { and } 2011 \text {. The choice of these years is dictated by the } \\
\text { data availability from the Census. Moreover, this strategy is ex- } \\
\text { pected to interpolate the situation at the beginning of the program- } \\
\text { ming period } 2007-2013 \text {. The CSO was the source of information. It } \\
\text { is anticipated that human capital facilitates knowledge and infor- } \\
\text { mation spillovers - one of the frequently mentioned characteristics } \\
\text { of agglomeration economies. }\end{array}$ \\
\hline $\begin{array}{l}\text { Entrepreneurial } \\
\text { density (ENTREP) }\end{array}$ & $\begin{array}{l}\text { The variable is defined as the share of employers and self- } \\
\text { employed people in the economically active population. The varia- } \\
\text { ble is again calculated as the mean of the years } 2001 \text { and } 2011 . \\
\text { The CSO was the source of information. The density of entrepre- } \\
\text { neurs is understood as a proxy of entrepreneurial climate (culture). }\end{array}$ \\
\hline $\begin{array}{l}\text { Unemployment } \\
\text { (UNEMPLOY) }\end{array}$ & $\begin{array}{l}\text { The variable is calculated as the proportion of registered unem- } \\
\text { ployed people for the population aged } 15-64 \text { in the years } 2005- \\
2007 \text { and it is log-transformed to improve normality. The data were } \\
\text { taken from the CSO. Unemployment was included to measure the } \\
\text { need for job creation. }\end{array}$ \\
\hline $\begin{array}{l}\text { Industrial structure } \\
\text { (INDUSTRY) }\end{array}$ & $\begin{array}{l}\text { The variable reflects the industrial structure of different regions, by } \\
\text { calculating the similarity to the "most advanced" industrial structure } \\
\text { of Prague. In this regard, the shares of } 11 \text { industries in employment } \\
\text { of each micro-region were computed. These shares were then used } \\
\text { to calculate the difference between each micro-region and Prague } \\
\text { for each industry. Finally, the differences corresponding to particu- } \\
\text { lar micro-regions were summed. Higher figures mean higher de- } \\
\text { grees of similarity. The variable is again calculated as the mean of } \\
\text { the years } 2001 \text { and } 2011 \text {. The CSO was the source of information. } \\
\text { The variable was included to consider the advancement of industri- } \\
\text { al structure, an important element of regional competitiveness. }\end{array}$ \\
\hline
\end{tabular}

Hájek et al. (2017), who expounded the demand side of the absorption capacity of regions in 
terms of the fundamental elements of the concept: (1) the capacity of actors to prepare and submit projects; (2) the capacity of actors to prepare and submit financially large projects; and (3) the capacity of actors to prepare and submit acceptable projects for financing by public funds. The question is whether less developed regions lag behind in the number of prepared and submitted projects, and/or in the financial size of prepared and submitted projects, and/or in the success rate of prepared and submitted projects. This is the third intention of this paper and its main innovative feature.

\section{Methodology}

To fulfil the goal of this paper, the following methodology was employed: firstly, socioeconomically disadvantaged regions were defined using the two above-mentioned approaches. The first approach was based on the indicators of socio-economic disadvantages of regions which were chosen by the traditional goals of enterprise support policies relating to competitiveness and job creation (Arshed et al. 2014, Dočekalová et al. 2015, Vega and Chiasson 2015). Moreover, the concepts of market imperfections and entrepreneurial culture (climate) were taken into account. Hence, six variables of socio-economic regional disadvantages were defined and these were entered into the principal component analysis (PCA) to generate uncorrelated components for the subsequent cluster analysis. Table 2 reviews the variables. Note that all the variables relate to: (1) the years preceding the start of the programming period 2007-2013; and (2) the 206 territories of the so-called administrative districts of municipalities with extended powers (hereafter referred to as micro-regions).

PCA was used to simplify the data structure by reducing the number of variables into a smaller number of orthogonal components. Note that the Kaiser-Meyer-Olkin measure of sampling adequacy confirmed the appropriateness of PCA (KMO > 0.60 as suggested by Tabachnick and Fidell 2007). The PCA procedure indicated that two components were extracted on the basis of the Kaiser criterion and on the basis of their theoretical underpinnings, and more than $70 \%$ of variance was explained by the two components. Table 3 reproduces the rotated component matrix, providing information on the component loadings of each variable. The two components are interpreted as representing: (1) the strength of agglomeration economies; and (2) the quality of entrepreneurial climate (culture). Moreover, the first component relates more to the competitiveness goal of enterprise support policies, whilst the second component relates more to the job creation goal of enterprise support policies. Hence, the two extracted components have an appealing interpretation and were used to define socio-economically disadvantaged micro-regions on the basis of cluster analysis.

Rotated component matrix (varimax rotation)

Table 3

\begin{tabular}{|l|r|r|}
\hline \multicolumn{1}{|c|}{ Variable } & Component 1 & \multicolumn{1}{c|}{ Component 2 } \\
\hline DENSITY & 0.857 & -0.268 \\
\hline INNOVATION & 0.517 & 0.450 \\
\hline TERTIARY & 0.780 & 0.452 \\
\hline ENTREP & 0.146 & 0.829 \\
\hline UNEMPLOY & -0.008 & -0.884 \\
\hline INDUSTRY & 0.787 & 0.176 \\
\hline
\end{tabular}

Source: Own elaboration based on the CSO (2002, 2008, 2012), and the IPO (2017)

The K-means clustering method was applied in order to classify the micro-regions into one of five categories (see Meyers et al. 2013 for the advantages of this method). The most appropriate number of clusters was determined by the Variance Ratio Criterion (Calinski and 
Harabasz 1974) and by the conceptual fit. Table 4 shows the final cluster centres for the fivecluster solution. See also Fig. 1, and the clusters may be interpreted in the following way: the first cluster includes the micro-regions characterized by the highest values of both agglomeration economies and the entrepreneurial climate (culture). Generally, these are the micro-regions of the main urban centres and their surroundings whose development potential is very high. Cluster 4 micro-regions also form urban agglomerations, but these are traditional industrial agglomerations of north-west Bohemia and Moravia-Silesia suffering from industrial decline and unemployment. The fifth cluster includes the micro-regions characterized by the lowest values of both agglomeration economies and entrepreneurial climate (culture). These are rather peripheral micro-regions, mainly located in the border areas. The remaining two clusters are positioned somewhere between the extremes of clusters 1, 4 and 5 . Overall, the cluster 5 micro-regions may be regarded as socio-economically disadvantaged regions, whilst the cluster 1 micro-regions may be regarded as core regions. The cluster 4 micro-regions have a specific position of being both socio-economically disadvantaged regions and core regions.

Final cluster centres ( $\mathbf{N}$ - number of territorial units classified into the cluster)

\begin{tabular}{|l|r|r|r|r|r|}
\hline \multicolumn{1}{|c|}{ Components } & Cluster 1 & Cluster 2 & Cluster 3 & \multicolumn{1}{c|}{ Cluster 4 } & \multicolumn{1}{c|}{ Cluster 5 } \\
\hline Component 1 & 2.00 & 0.35 & -0.57 & 1.64 & -0.61 \\
\hline Component 2 & 1.34 & 0.01 & 0.71 & -1.86 & -0.87 \\
\hline$N$ & 15 & 57 & 69 & 13 & 52 \\
\hline
\end{tabular}

Source: Own elaboration based on the CSO $(2002,2008,2012)$, and the IPO (2017)

The second approach to define socio-economically disadvantaged regions was based on the Czech Government resolutions No. 829/2006 and No. 141/2010, that proclaimed the government's commitment to provide special assistance to selected disadvantaged microregions in the Czech Republic. For the purpose of this paper, the micro-regions that were selected for both resolutions are taken to be socio-economically disadvantaged regions. Table 5 points out a close relationship between the both approaches for defining socio-economically disadvantaged regions; however this relationship is far from perfect.

The spatial distribution of SF was evaluated regarding the categories of micro-regions, as

Table 5

Number of micro-regions; the relationship between the two approaches for defining socio-economically disadvantaged regions

\begin{tabular}{|l|r|r|r|r|r|}
\hline $\begin{array}{c}\text { Socio-economically } \\
\text { disadvantaged regions }\end{array}$ & Cluster $\mathbf{1}$ & Cluster $\mathbf{2}$ & Cluster $\mathbf{3}$ & Cluster $\mathbf{4}$ & Cluster 5 \\
\hline Yes $^{*}$ & 0 & 14 & 1 & 10 & 31 \\
\hline No* $^{*}$ & 15 & 43 & 68 & 3 & 21 \\
\hline
\end{tabular}

*According to Czech Government resolutions No. 829/2006 and No. 141/2010

Source: own elaboration based on the CSO (2002, 2008, 2012), the IPO (2017), and Czech Government resolutions No. 829/2006 and No. 141/2010

defined in the above-mentioned approaches. The evaluation was based on all SF interventions that were supported either from the Convergence Objective or from the Regional 


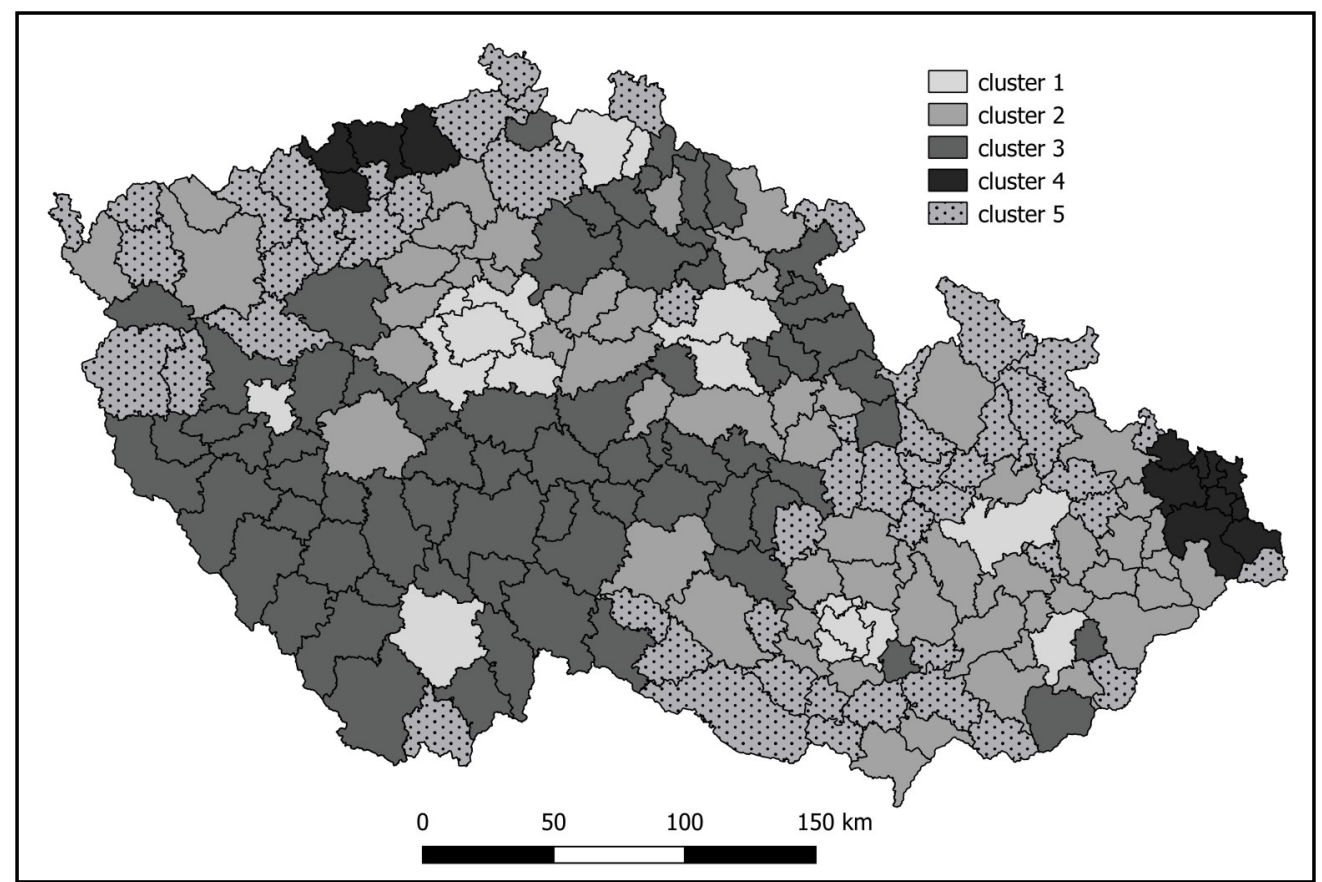

Fig. 1 - Clusters of micro-regions - spatial pattern

Source: Own elaboration based on the CSO $(2002,2008,2012)$, and the IPO (2017)

defined in the above-mentioned approaches. The evaluation was based on all SF interventions that were supported either from the Convergence Objective or from the Regional Competitiveness and Employment Objective in the programming period 2007-2013. Also, these interventions were categorized as enterprise support interventions. In this way, SF interventions from four thematic operational programmes (hereafter referred to as TOPs) and nine regional operational programmes (hereafter referred to as ROPs) were included in subsequent analyses, particularly:

- TOP Enterprise and Innovation - SF interventions focusing on innovations, new business formation, firm growth, the entrepreneurial environment, enterprise support services, and energy efficiency in enterprises,

- $\quad$ TOP Human Resources and Employment - SF interventions focusing on human resource development in enterprises,

- TOP Research and Development for Innovations - SF interventions focusing on research, development and innovations in enterprises,

- TOP Environment - SF interventions focusing on environmental risk reduction,

- ROP Central Bohemia, ROP Central Moravia, ROP Moravia-Silesia, ROP North-East, ROP North-West, ROP South-East, and ROP South-West - SF interventions especially focusing on tourism development,

- ROP Prague-Competitiveness and ROP Prague-Adaptability - SF interventions focusing on innovations, enterprises and the knowledge economy. 
Note that apart from TOP Enterprise and Innovation, only SF interventions carried out by private-sector beneficiaries were included in subsequent analyses. Additionally, SF interventions were divided into two types: (1) innovation-oriented interventions (hereafter referred to as type 1 interventions); and (2) other enterprise support interventions (e.g., new business formation, firm growth, entrepreneurial environment, enterprise support services, human resource development in enterprises, energy efficiency in enterprises, and tourism development; hereafter referred to as the type 2 interventions). The spatial distribution of SF was then analysed: (1) for all interventions; (2) for type 1 interventions only; and (3) for type 2 interventions only.

The overall spatial pattern of SF allocation is influenced by the spatial concentration of SF allocation for particular thematic areas. SF allocation for type 2 interventions may particularly be expected to indicate more even spatial distribution than SF allocation for type 1 interventions. Therefore, the position of lagging regions is assumed to be better for type 2 interventions. The fact that Prague was ineligible to draw funds from the most generous Convergence Objective is of particular importance here. SF allocation for cluster 1 microregions should therefore be influenced by a lower SF allocation to Prague, notably for type 2 interventions, because SF interventions from the two Prague ROPs were mostly categorized as type 1 interventions. However, it is worth noting that the strength of the "Prague effect" may be weakened by a higher SF allocation to neighbouring cluster 1 micro-regions (Fig. 1), which are eligible for financing from the Convergence Objective.

The evaluation proceeded as follows: firstly, the SF allocation, standardized by the number of inhabitants to consider the different sizes of micro-regions, was calculated for each of the 206 micro-regions. The mean values of SF allocation for each micro-region was then calculated for each category of micro-regions, and then compared to one another, using appropriate methods of descriptive and inferential statistics. The statistical significance of mean differences was determined using the independent samples t-test in cases of socio-economically disadvantaged regions, defined on the basis of the two Czech Government resolutions, and using one-way ANOVA, followed by post-hoc comparisons of means by Bonferroni's method in the cases of the five clusters of micro-regions. Note that the SF allocation per capita variable was logtransformed to fulfil the assumption of normality for statistical tests. The sources of information were the official data from June 2016, published by the Ministry of Regional Development of the Czech Republic (hereafter referred to as the MRD CR), the Ministry of Industry and Trade of the Czech Republic (hereafter referred to as the MIT CR) and the Ministry of Labour and Social Affairs of the Czech Republic (hereafter referred to as the MLSA CR).

The absorption capacity of the different categories of micro-regions was evaluated, using the theoretical approach suggested by Hájek et al. (2017). The three fundamental elements of the absorption capacity concept were operationalized in the following way: (1) the capacity of actors in a micro-region to prepare and submit projects, shown as the number of supported and unsupported interventions per 10000 inhabitants of the micro-region (hereafter referred to as NUMBER OF PROJECTS); (2) the capacity of actors in a micro-region to prepare and submit financially large projects measured as the average size of both, supported and unsupported interventions that were submitted for realization in the micro-region (hereafter referred to as PROJECT SIZE); and (3) the capacity of actors in a micro-region to prepare and submit acceptable projects for financing by using public funds, shown as the success rate of interventions submitted for realization in the micro-region (hereafter referred to as SUCCESS RATE). Once again, the mean values of the three variables of the absorption capacity concept per micro-region were calculated for each category of micro-regions, and also for the three types of evaluation: (1) for all interventions; (2) for type 1 interventions only; and (3) for type 2 interventions only. Then, the micro-region values were ranked into terciles and the tercile distribution of micro-regions for each category of micro-regions was obtained. Finally, the differences in these distributions between the categories of micro-regions were discussed, 
considering their relationship to SF allocation. The sources of information remained the same as for the SF allocation per inhabitant variable.

\section{Results and Discussion}

This evaluation is based on more than $32600 \mathrm{SF}$ interventions and on more than CZK 161 billion. Almost $50 \%$ of SF interventions and more than $58 \%$ of financial allocation were categorized as type 1 interventions.

Table 6 provides initial insight into the distribution of SF among the defined categories of microregions. The mean values are reported: (1) for all interventions; (2) for type 1 interventions; and (3) for type 2 interventions. Inspection of Table 6 reveals that relatively more SF is allocated to cluster 1 and to cluster 2 micro-regions, whereas cluster 3 and cluster 4 micro-regions indicate relatively lower SF allocation. These findings are similar for both types of interventions, except that the position of cluster 1 micro-regions is weakened when only considering type 2 interventions. The "Prague effect" partially explains this fact. Concerning socio-economically disadvantaged regions defined by the Czech Government resolutions, the total SF allocation is almost the same for both types of micro-regions. However, socio-economically disadvantaged micro-regions indicate higher SF allocation for type 1 interventions, but lower SF allocation for type 2 interventions. Additionally, as shown by the independent samples t-test results, the mean differences are significant at the 0.01 level for type 1 interventions $(p=0.008)$ and at the 0.05 level for type 2 interventions $(p=0.023)$ respectively.

One-way ANOVA followed by post-hoc Bonferroni tests expounded the initial findings by

Table 6

\section{SF allocation per inhabitant (in CZK) - mean value per micro-region (standard deviations in parentheses)}

\begin{tabular}{|c|c|c|c|c|c|c|c|}
\hline \multirow{2}{*}{$\begin{array}{c}\text { Type of } \\
\text { evaluation }\end{array}$} & \multicolumn{5}{|c|}{ Clusters } & \multicolumn{2}{|c|}{ Resolutions* } \\
\hline & 1 & 2 & 3 & 4 & 5 & Yes & No \\
\hline $\begin{array}{l}\text { SF allocation - } \\
\text { all } \\
\text { interventions }\end{array}$ & $\begin{array}{r}17732 \\
(6805)\end{array}$ & $\begin{array}{r}17965 \\
(8462)\end{array}$ & $\begin{array}{r}13470 \\
(6311)\end{array}$ & $\begin{array}{r}11128 \\
(5883)\end{array}$ & $\begin{array}{l}16099 \\
(9835)\end{array}$ & $\begin{array}{l}15658 \\
(6737)\end{array}$ & $\begin{array}{l}15496 \\
(8666)\end{array}$ \\
\hline $\begin{array}{l}\text { SF allocation - } \\
\text { type } 1 \text { inter- } \\
\text { ventions }\end{array}$ & $\begin{array}{r}11808 \\
(5748)\end{array}$ & $\begin{array}{c}10347 \\
(5029)\end{array}$ & $\begin{array}{r}6838 \\
(4889)\end{array}$ & $\begin{array}{r}6870 \\
(4630)\end{array}$ & $\begin{array}{r}9028 \\
(5398)\end{array}$ & $\begin{array}{c}10141 \\
(5278)\end{array}$ & $\begin{array}{r}8198 \\
(5277)\end{array}$ \\
\hline $\begin{array}{l}\text { SF allocation - } \\
\text { type } 2 \text { inter- } \\
\text { ventions }\end{array}$ & $\begin{array}{r}5924 \\
(1971)\end{array}$ & $\begin{array}{r}7617 \\
(6143)\end{array}$ & $\begin{array}{r}6632 \\
(3830)\end{array}$ & $\begin{array}{r}4257 \\
(2233)\end{array}$ & $\begin{array}{r}7070 \\
(7926)\end{array}$ & $\begin{array}{r}5517 \\
(3748)\end{array}$ & $\begin{array}{r}7298 \\
(6167)\end{array}$ \\
\hline
\end{tabular}

*Socio-economically disadvantaged regions according to Czech Government resolutions No. 829/2006 and No. 141/2010.

Source: own elaboration based on the CSO $(2002,2008,2012)$, the IPO (2017), the MIT CR, the MLSA CR, the MRD CR (2017), and Czech Government resolutions No. $829 / 2006$ and No. $141 / 2010$

assessing pairwise multiple comparisons of cluster means, and also by examining the significance of mean differences. Just to recap, log-transformed variables were used to fulfil the assumption of normality. The results appeared to be significant at the 0.01 and 0.05 levels in two situations. Firstly, the SF allocation mean for all interventions is significantly higher in 
cluster 2 micro-regions than in cluster $3(p=0.023)$ micro-regions, and cluster $4(p=0.014)$ micro -regions. Secondly, the SF allocation mean for type 1 interventions is significantly lower in cluster 3 micro-regions than in cluster $1(p=0.012)$ micro-regions and cluster $2(p=0.001)$ microregions.

The above-mentioned statistics reveal several interesting findings. Socio-economically disadvantaged regions do not generally have a high SF allocation per inhabitant, except for the two Czech Government resolutions and also for the innovation-oriented interventions (type 1). This position of socio-economically disadvantaged regions is particularly obvious in cluster 4 micro-regions that include traditional industrial agglomerations, which suffer from industrial decline, that have a poor entrepreneurial climate (culture) and which have significant unemployment. The low SF allocation per inhabitant to cluster 4 micro-regions is in sharp contrast to cluster 1 micro-regions that include agglomerations with a strong entrepreneurial climate (culture) and that indicate relatively high SF allocation per inhabitant, especially for innovation-oriented interventions. A relatively low SF allocation is observed also in the microregions, characterized by the absence of strong agglomeration economies and by a relatively strong entrepreneurial climate (culture) and low unemployment (cluster 3 ). In the absence of strong agglomeration economies, a better entrepreneurial climate and low unemployment do not lead to a higher SF allocation, as indicated by the comparison of cluster 3 micro-regions and cluster 5 micro-regions.

The question is why some categories of micro-regions perform better in SF allocation per inhabitant than others. The variables of the absorption capacity concept are used to partially explain this question. In this regard, Tables 7, 8 and 9 provide the tercile distribution of microregions for each variable of the absorption capacity concept and for each category of microregions. The following findings are worth noting:

- $\quad$ Cluster 1 micro-regions indicate a relatively high number of projects prepared and submitted for financing from SF. Moreover, these projects tend to be financially demanding, particularly if they are innovation-oriented interventions. However, cluster 1 micro-regions are relatively less successful in projects being approved for financing. This is partially explained by a lower acceptance rate of projects that were submitted for financing in Prague.

- It seems to be a problem that there are a relatively low number of projects prepared and submitted for financing from SF for cluster 3 micro-regions, particularly for innovationoriented interventions. Moreover, these projects are relatively less successful in the approval procedure. The opposite is true for cluster 5 micro-regions, which explains the differences in SF allocation per inhabitant to the two clusters of micro-regions. Note a relatively smaller size of projects prepared and submitted in cluster 5 micro-regions.

- $\quad$ There are a relatively low number of projects prepared and submitted for financing from SF for cluster 4 micro-regions, particularly for type 2 interventions, which seems to be a problem. Hence, the low capacity to prepare and submit projects for financing from SF may be regarded as the main source of lower SF allocation in cluster 4 micro-regions.

- $\quad$ The micro-regions, categorized as socio-economically disadvantaged regions according to Czech Government resolutions, tend to prepare and submit more projects for type 1 interventions but not for type 2 interventions. Additionally, these micro-regions are slightly more successful in the approval procedure; however, the size of prepared and submitted projects is financially less demanding in this category of micro-regions.

Overall, the findings provide evidence on the relationship between SF allocation and the absorption capacity concept. A relatively low number of projects prepared and submitted for financing from SF seem to be crucial for understanding the relatively low SF allocation for 
cluster 3 and cluster 4 micro-regions.

The main research question of this paper is whether the spatial distribution of SF follows the

Table 7

NUMBER OF PROJECTS - the share of micro-regions in a category falling in the bottom, middle and top terciles of the variable

\begin{tabular}{|l|r|r|r|r|r|c|c|c|c|}
\hline \multirow{2}{*}{$\begin{array}{l}\text { Evaluation, } \\
\text { category }\end{array}$} & \multicolumn{3}{|c|}{ All interventions } & \multicolumn{2}{c|}{ Type 1 interventions } & \multicolumn{2}{|c|}{ Type 2 interventions } \\
\cline { 2 - 10 } & $\begin{array}{c}\text { Bot- } \\
\text { tom }\end{array}$ & $\begin{array}{c}\text { Mid- } \\
\text { dle }\end{array}$ & Top & $\begin{array}{c}\text { Bot- } \\
\text { tom }\end{array}$ & $\begin{array}{c}\text { Mid- } \\
\text { dle }\end{array}$ & Top & $\begin{array}{c}\text { Bot- } \\
\text { tom }\end{array}$ & $\begin{array}{c}\text { Mid- } \\
\text { dle }\end{array}$ & Top \\
\hline $\begin{array}{l}\text { Clusters - } \\
\text { cluster 1 }\end{array}$ & $7 \%$ & $53 \%$ & $40 \%$ & $20 \%$ & $33 \%$ & $47 \%$ & $0 \%$ & $33 \%$ & $67 \%$ \\
\hline $\begin{array}{l}\text { Clusters - } \\
\text { cluster 2 }\end{array}$ & $19 \%$ & $46 \%$ & $35 \%$ & $21 \%$ & $33 \%$ & $46 \%$ & $26 \%$ & $42 \%$ & $32 \%$ \\
\hline $\begin{array}{l}\text { Clusters - } \\
\text { cluster 3 }\end{array}$ & $45 \%$ & $25 \%$ & $30 \%$ & $56 \%$ & $28 \%$ & $16 \%$ & $32 \%$ & $27 \%$ & $41 \%$ \\
\hline $\begin{array}{l}\text { Clusters - } \\
\text { cluster 4 }\end{array}$ & $69 \%$ & $23 \%$ & $8 \%$ & $39 \%$ & $46 \%$ & $15 \%$ & $61 \%$ & $31 \%$ & $8 \%$ \\
\hline $\begin{array}{l}\text { Clusters - } \\
\text { cluster 5 }\end{array}$ & $33 \%$ & $29 \%$ & $38 \%$ & $19 \%$ & $39 \%$ & $42 \%$ & $46 \%$ & $33 \%$ & $21 \%$ \\
\hline $\begin{array}{l}\text { Resolutions } \\
- \text { Yes }\end{array}$ & $25 \%$ & $32 \%$ & $43 \%$ & $11 \%$ & $34 \%$ & $55 \%$ & $48 \%$ & $36 \%$ & $16 \%$ \\
\hline $\begin{array}{l}\text { Resolutions } \\
\text { - No }\end{array}$ & $37 \%$ & $34 \%$ & $29 \%$ & $42 \%$ & $33 \%$ & $25 \%$ & $28 \%$ & $33 \%$ & $39 \%$ \\
\hline
\end{tabular}

*Socio-economically disadvantaged regions according to Czech Government resolutions No. $829 / 2006$ and No. $141 / 2010$

Source: own elaboration based on the CSO $(2002,2008,2012)$, the IPO (2017), the MIT CR, the MLSA CR, the MRD CR, and Czech Government resolutions No. 829/2006 and No. 141/2010

territorial cohesion objectives specified in the strategic documents of the Czech Republic in the programming period 2007-2013 (Table 1). The empirical results of this section enable us to obtain answers. Concerning the research and development, and also the innovation-oriented objectives, some evidence is provided suggesting a higher SF allocation for innovation-oriented interventions to core micro-regions of the Czech Republic (cluster 1). Additionally, the capacity to prepare and submit a high number of large innovation-oriented projects is high in cluster 1 micro-regions. However, this is not the case of the structurally disadvantaged agglomerations (cluster 4 micro-regions) that particularly suffer from a relatively low number of submitted projects. Concerning the objectives related to the support of socio-economically disadvantaged regions, the findings are ambivalent. Nevertheless, the evidence does not seem to support the arguments that socio-economically disadvantaged micro-regions receive more SF. Consequently, doubts are also cast on the coherence between regional and structural policies.

There may be several practical implications of these research results. Considering the spatial distribution of SF allocation among the Czech Republic's micro-regions, there is a rather limited evidence supporting the territorial cohesion objectives specified in the strategic documents of the Czech Republic in the 2007-2013 programming period. The spatial concentration of SF allocation seems to be insufficient, especially in terms of the balanced development objective. In this regard, it is appropriate to consider strengthening the importance of territorially based instruments (e.g., local action groups). This is particularly relevant for micro-regions characterised by low absorption capacity. The link between core regions and innovationoriented interventions is notably more apparent. However, Prague's ineligibility for financing 
PROJECT SIZE - the share of micro-regions in a category falling in the bottom, middle and top terciles of the variable

\begin{tabular}{|l|c|c|c|c|c|c|c|c|c|}
\hline \multirow{2}{*}{$\begin{array}{l}\text { Evaluation, } \\
\text { category }\end{array}$} & \multicolumn{3}{|c|}{ All interventions } & \multicolumn{3}{c|}{ Type 1 interven- } & \multicolumn{3}{c|}{ Type 2 interven- } \\
tions \\
\cline { 2 - 10 } & $\begin{array}{c}\text { Bot- } \\
\text { tom }\end{array}$ & $\begin{array}{c}\text { Mid- } \\
\text { dle }\end{array}$ & Top & $\begin{array}{c}\text { Bot- } \\
\text { tom }\end{array}$ & $\begin{array}{c}\text { Mid- } \\
\text { dle }\end{array}$ & Top & $\begin{array}{c}\text { Bot- } \\
\text { tom }\end{array}$ & $\begin{array}{c}\text { Mid- } \\
\text { dle }\end{array}$ & Top \\
\hline $\begin{array}{l}\text { Clusters - } \\
\text { cluster 1 }\end{array}$ & $13 \%$ & $67 \%$ & $20 \%$ & $7 \%$ & $27 \%$ & $66 \%$ & $47 \%$ & $53 \%$ & $0 \%$ \\
\hline $\begin{array}{l}\text { Clusters - } \\
\text { cluster 2 }\end{array}$ & $37 \%$ & $30 \%$ & $33 \%$ & $30 \%$ & $39 \%$ & $31 \%$ & $41 \%$ & $26 \%$ & $33 \%$ \\
\hline $\begin{array}{l}\text { Clusters - } \\
\text { cluster 3 }\end{array}$ & $28 \%$ & $36 \%$ & $38 \%$ & $36 \%$ & $28 \%$ & $36 \%$ & $23 \%$ & $38 \%$ & $39 \%$ \\
\hline $\begin{array}{l}\text { Clusters - } \\
\text { cluster 4 }\end{array}$ & $31 \%$ & $31 \%$ & $38 \%$ & $31 \%$ & $38 \%$ & $31 \%$ & $38 \%$ & $31 \%$ & $31 \%$ \\
\hline $\begin{array}{l}\text { Clusters - } \\
\text { cluster 5 }\end{array}$ & $44 \%$ & $25 \%$ & $31 \%$ & $42 \%$ & $37 \%$ & $21 \%$ & $34 \%$ & $31 \%$ & $35 \%$ \\
\hline $\begin{array}{l}\text { Resolutions } \\
\text { Yes }\end{array}$ & $43 \%$ & $30 \%$ & $27 \%$ & $45 \%$ & $37 \%$ & $18 \%$ & $38 \%$ & $39 \%$ & $23 \%$ \\
\hline $\begin{array}{l}\text { Resolutions } \\
\text { No }-\end{array}$ & $30 \%$ & $35 \%$ & $35 \%$ & $29 \%$ & $32 \%$ & $39 \%$ & $32 \%$ & $31 \%$ & $37 \%$ \\
\hline
\end{tabular}

*Socio-economically disadvantaged regions according to Czech Government resolutions No. 829/2006 and No. $141 / 2010$

Source: own elaboration based on the CSO $(2002,2008,2012)$, the IPO (2017), the MIT CR, the MLSA CR, the MRD CR, and Czech Government resolutions No. 829/2006 and No. 141/2010

from the Convergence Objective undermines the strength of this link. Additionally, the results suggest focusing more on the entrepreneurial climate of traditional industrial agglomerations regarding the low absorption capacity of these micro-regions. Territorially based instruments (e.g., integrated territorial instruments) may also be regarded as relevant in this case.

The research results further indicate that SF allocation differs depending on the SF intervention type used. Innovation-oriented interventions favour core regions, while other enterprise support interventions are more important for peripheral micro-regions. Consequently, the SF allocation split between the two types of SF interventions influences which micro-regions receive more SF. In this way, the research results are useful for scenario building as well as for Territorial Impact Assessment (hereafter referred to as TIA) methodologies. Two additional points are worth noting. Firstly, there are sizeable differences in the research results between the two approaches defining the socio-economically disadvantaged regions. This indicates the relevance of politics here. Secondly, the absorption capacity concept is crucially important in explaining the SF allocation, and this substantiates various measures which strengthen the absorption capacity of micro-regions. Overall, these research results emphasize the need to consider the complex relations between the territorial cohesion objectives and the enterprise support policies.

\section{Conclusions}

The goal of this paper is to assess whether the spatial distribution of SF for enterprise support interventions follows the relevant territorial cohesion objectives specified in the strategic documents of the Czech Republic in the programming period 2007-2013. Overall, the empirical 
SUCCESS RATE - the share of micro-regions in a category falling in the bottom, middle and top terciles of the variable

\begin{tabular}{|l|c|c|c|c|c|c|c|c|c|}
\hline \multirow{2}{*}{$\begin{array}{c}\text { Evalua- } \\
\text { tion, } \\
\text { category }\end{array}$} & \multicolumn{3}{|c|}{ All interventions } & \multicolumn{2}{c|}{ Type 1 interventions } & \multicolumn{3}{c|}{$\begin{array}{c}\text { Type 2 } \\
\text { interventions }\end{array}$} \\
\cline { 2 - 10 } & $\begin{array}{c}\text { Bot- } \\
\text { tom }\end{array}$ & $\begin{array}{c}\text { Mid- } \\
\text { dle }\end{array}$ & Top & $\begin{array}{c}\text { Bot- } \\
\text { tom }\end{array}$ & $\begin{array}{c}\text { Mid- } \\
\text { dle }\end{array}$ & Top & $\begin{array}{c}\text { Bot- } \\
\text { tom }\end{array}$ & $\begin{array}{c}\text { Mid- } \\
\text { dle }\end{array}$ & $\begin{array}{c}\text { To } \\
\text { p }\end{array}$ \\
\hline $\begin{array}{l}\text { Clusters - } \\
\text { cluster 1 }\end{array}$ & $47 \%$ & $33 \%$ & $20 \%$ & $27 \%$ & $60 \%$ & $13 \%$ & $33 \%$ & $53 \%$ & $\begin{array}{r}14 \\
\%\end{array}$ \\
\hline $\begin{array}{l}\text { Clusters - } \\
\text { cluster 2 }\end{array}$ & $19 \%$ & $35 \%$ & $46 \%$ & $23 \%$ & $40 \%$ & $37 \%$ & $23 \%$ & $37 \%$ & $\begin{array}{r}40 \\
\%\end{array}$ \\
\hline $\begin{array}{l}\text { Clusters - } \\
\text { cluster 3 }\end{array}$ & $46 \%$ & $25 \%$ & $29 \%$ & $41 \%$ & $20 \%$ & $39 \%$ & $41 \%$ & $26 \%$ & $\begin{array}{r}33 \\
\%\end{array}$ \\
\hline $\begin{array}{l}\text { Clusters - } \\
\text { cluster 4 }\end{array}$ & $31 \%$ & $23 \%$ & $46 \%$ & $39 \%$ & $23 \%$ & $38 \%$ & $31 \%$ & $31 \%$ & $\begin{array}{r}38 \\
\%\end{array}$ \\
\hline $\begin{array}{l}\text { Clusters - } \\
\text { cluster 5 }\end{array}$ & $29 \%$ & $46 \%$ & $25 \%$ & $37 \%$ & $38 \%$ & $25 \%$ & $36 \%$ & $35 \%$ & $\begin{array}{r}29 \\
\%\end{array}$ \\
\hline $\begin{array}{l}\text { Resolu- } \\
\text { tions } \\
\text { Yes }\end{array}$ & $27 \%$ & $27 \%$ & $46 \%$ & $34 \%$ & $33 \%$ & $33 \%$ & $34 \%$ & $28 \%$ & $\begin{array}{r}38 \\
\%\end{array}$ \\
\hline $\begin{array}{l}\text { Resolu- } \\
\text { tions }\end{array}$ & $36 \%$ & $36 \%$ & $28 \%$ & $34 \%$ & $34 \%$ & $32 \%$ & $34 \%$ & $35 \%$ & 31 \\
$\%$
\end{tabular}

*Socio-economically disadvantaged regions according to Czech Government resolutions No. $829 / 2006$ and No. $141 / 2010$

Source: own elaboration based on the CSO $(2002,2008,2012)$, the IPO (2017), the MIT CR, the MLSA CR, the MRD CR, and Czech Government resolutions No. 829/2006 and No. 141/2010

results provide mixed evidence.

The competitiveness objective seems to be supported by a relatively high SF allocation to the micro-regions, characterized by strong agglomeration economies and entrepreneurial climate (culture). This may be particularly observed when innovation-oriented interventions are evaluated. Moreover, the absorption capacity of these micro-regions appears to be relatively high, indicating the potential to strengthen the importance of the competitiveness objective. The empirical results give, on the contrary, little support to the objective of balanced development. Socio-economically disadvantaged micro-regions do not receive a higher SF allocation. Additionally, urban agglomerations, suffering from industrial decline, high unemployment and weak entrepreneurial climate (culture) even lag behind in SF allocation due to their low capacity to prepare and submit a relatively high number of projects for SF financing. However, an exception may be noticed. The socio-economically disadvantaged micro-regions defined on the basis of the Czech Government resolutions have a higher SF allocation for innovation-oriented interventions. Hence, a low absorption capacity of socioeconomically disadvantaged micro-regions particularly for innovation-oriented interventions is not confirmed (compare this with Kaufmann and Wagner 2005, Klímová and Žítek 2015).

The empirical results of this paper have several policy implications. The results provide limited evidence to support the territorial cohesion objectives specified in the strategic documents of the Czech Republic in the programming period 2007-2013. This is due to the low spatial concentration of SF allocation. Therefore, the first policy recommendation is to consider using territorially based instruments to increase the spatial concentration of SF allocation in 
accordance with the territorial cohesion objectives. Furthermore, the spatial distributions of SF were found to differ between innovation-oriented interventions and other enterprise support interventions. Therefore, the thematic focus of enterprise support interventions are relevant in evaluating territorial cohesion objectives, and the coherence between regional and structural policies may be increased when considering the SF allocation split between particular thematic areas. This approach may be also relevant for scenario building and for TIA methodologies. Additionally, there is a broad spread of results due to the different approaches to define socioeconomically disadvantaged regions. It seems that a more nuanced approach to the definition and measurement of socio-economic regional disadvantages may have fruitful implications for the territorial cohesion objectives. Finally, it was shown that the SF absorption concept crucially influences the SF allocation in micro-regions. The last policy recommendation here emphasises the steps focusing on strengthening the absorption capacity of micro-regions. The territorial cohesion objectives have a complex nature which must be considered.

The paper also provides a methodological framework for evaluating the relations between the public policy and the territorial cohesion objectives. There are, however, some research limitations in this regard. Firstly, the choice of variables regarding the socio-economic disadvantages, which is of great importance for the results, is limited by the lack of data at micro-regional level. It is therefore desirable to search for other ways to process information on the socio-economic disadvantages of micro-regions. Secondly, this paper deals with the SF allocation but it does not deal with the link between the SF allocation and the output/outcome indicators. Nevertheless, this particular link may be crucial for recognizing the territorial impacts of public policies. Thirdly, there is a vast debate about the suitable spatial level of similar analyses. The strengths and weaknesses of two types of regions are also discussed, notably functional regions and administrative regions. Therefore, the results ought to be compared while giving regard to different types of spatial units. These limitations are also suggestions for further research.

\section{Acknowledgements}

The authors are thankful for the grant no. 16-22141S provided by the Czech Science Foundation for financial support to carry out this research. The data provision from the Czech Statistical Office (the Zlín Office) is also kindly acknowledged.

\section{References}

ACS Z., ASTEBRO T., AUDRETSCH D., ROBINSON D. T. (2016), Public policy to promote entrepreneurship: a call to arms, Small Business Economics 47 (1), 35-51.

ACS Z. J., SZERB L. (2007), Entrepreneurship, economic growth and public policy, Small Business Economics 28 (2-3), 109-122.

ARSHED N., CARTER S., MASON C. (2014), The ineffectiveness of entrepreneurship policy: is policy formulation to blame?, Small Business Economics 43 (3), 639-659.

AUDRETSCH D. B. (2004), Sustaining innovation and growth: Public policy support for entrepreneurship, Industry and innovation 11 (3), 167-191.

AUDRETSCH D. B. (2015), The strategic management of place, in: Audretsch D. B., Link A. N., Walshok M. L. (eds.), The Oxford Handbook of Local Competitiveness, Oxford University Press, Oxford, pp. 13-33.

BLAŽEK J., MACEŠKOVÁ M. (2010), Regional analysis of public capital expenditure: to which regions is public capital expenditure channelled - to 'rich' or to 'poor' ones?, Regional Studies 44 (6), 679-696.

BONFIGLIO A., CAMAIONI B., CODERONI S., ESPOSTI R., PAGLIACCI F., SOTTE F. (2016), Where does EU money eventually go? The distribution of CAP expenditure across the European space, Empirica 43 (4), 693-727.

BOUVET F., DALL'ERBA S. (2010), European regional structural funds: how large is 
the influence of politics on the allocation process?, Journal of Common Market Studies 48 (3), 501-528.

CACE C., CACE S., IOVA C., NICOLAESCU V. (2009), Absorption capacity of the structural funds. Integrating perspectives, Revista de cercetare şi intervenţie socială 27 (1), 728.

CALINSKI T., HARABASZ J. (1974), A dendrite method for cluster analysis, Communications in Statistics 3 (1), 1-27.

CAMAIONI B., ESPOSTI R., LOBIANCO A., PAGLIACCI F., SOTTE F. (2013), How rural is the EU RDP? An analysis through spatial fund allocation, Bio-based and Applied Economics 2 (3), 277-300.

COLOMB C., SANTINHA G. (2014), European Union competition policy and the European territorial cohesion agenda: An impossible reconciliation? State aid rules and public service liberalization through the European spatial planning lens, European Planning Studies 22 (3), 459-480.

CRESCENZI R. (2009), Undermining the principle of concentration? European Union regional policy and the socio-economic disadvantage of European regions, Regional Studies 43 (1), 111-133.

CRESCENZI R., DE FILLIPIS F., PIERANGELI F. (2015), In tandem for cohesion? Synergies and conflicts between regional and agricultural policies of the European Union, Regional Studies 49 (4), 681-704.

CSO (2002), 2001 Census Results [DVD], Czech Statistical Office, Prague.

Office, Prague.

CSO (2008), Territorial Analytical Data 2005, 2006, 2007 [DVD], Czech Statistical CSO (2012), 2011 Census Results [DVD], Czech Statistical Office, Prague.

DELLMUTH L. M. (2011), The cash divide: the allocation of European Union regional grants, Journal of European Public Policy 18 (7), 1016-1033.

DELLMUTH L. M., STOFFEL M. F. (2012), Distributive politics and intergovernmental transfers: the local allocation of European Union structural funds, European Union Politics 13 (3), 413-433.

DOČEKALOVÁ M., KOCMANOVÁ A., KOLEŇÁK J. (2015), Determination of economic indicators in the context of corporate sustainability performance, Business: Theory and Practice 16 (1), 15-24.

DOLINSKÁ V., AMBROZOVÁ E. (2015), Problems of organizational culture in economic and educational environment, Scientia \& Societas 11 (1), 88-98.

DURAN M. (2014), The absorption capacity of Turkey for its use of the European Union pre-accession assistance, Bogazici Journal Review of Social, Economic and Administrative Studies 28 (1), 69-93.

HÁJEK O., SMÉKALOVÁ L., NOVOSÁK J., ZAHRADNÍK P. (2014), Prostorová koherence národni a evropské regionální politiky: poznatky z České republiky a Slovenska [Spatial coherence of national and European regional policy: The insights from the Czech Republic and Slovakia], Politická ekonomie 62 (5), 630-644.

HÁJEK O., NOVOSÁK J., HORVÁTH P., NOVOSÁKOVÁ J. (2017), Absorpční kapacita strukturálních fondů (2007-2013): typologie českých mikroregionů [Absorption capacity of structural funds (2007-2013): typology of Czech microregions], Scientific Papers of the University of Pardubice. Series D 39 (1), 28-38.

HENRY C., HILL F., LEITCH C. (2003), Developing a coherent enterprise support policy: a new challenge for governments, Environment and Planning C: Politics and Space 21 (1), 3-19.

HUGGINS R., WILLIAMS N. (2009), Enterprise and public policy: a review of labour government intervention in the United Kingdom, Environment and Planning C: Politics and Space 27 (1), 19-41.

IATU C., ALUPULUI C. (2011), Structural funds' absorption in Romania: factor analysis of NUTS 3 level, Transformations in Business \& Economics 10 (2b), 612-630.

IPO (2017), Patent and Utility Model Databases. National Database, Industrial Property 
Office, Retrieved from: www.upv.cz.

JANÍČEK P., VAIGEL R. (2016), European Social Fund investments in the Czech Republic and Slovakia, International Journal of Public Administration, Management and Economic Development 1 (1), 19-28.

KAUFMANN A., WAGNER P. (2005), EU regional policy and the stimulation of innovation: the role of the European Regional Development Fund in the Objective 1 region Burgenland, European Planning Studies 13 (4), 581-599.

KEMMERLING A., BODENSTEIN T. (2006), Partisan politics in regional redistribution. Do parties affect the distribution of EU structural funds across regions?, European Union Politics 7 (3), 373-392.

KLİMOVÁ V., ŽíTEK V. (2015), Inovační paradox v Česku: ekonomická teorie a politická realita [Innovation paradox in the Czech Republic: Economic theory and political reality], Politická ekonomie 63 (2), 147-166.

LEE S. Y., FLORIDA R., ACS Z. (2004), Creativity and entrepreneurship: a regional analysis of new firm formation, Regional Studies 38 (8), 879-891.

LOLOS S. E. G. (2009), The effect of EU structural funds on regional growth: assessing the evidence from Greece, 1990-2005, Economic Change and Restructuring 42 (3), 211-228.

LUCA D., RODRÍGUEZ-POSE A. (2015), Distributive politics and regional development: assessing the territorial distribution of Turkey's public investment, The Journal of Development Studies 51 (11), 1518-1540.

MEYERS L. S., GAMST G. C., GUARINO A. J. (2013), Performing Data Analysis Using IBM SPSS, Wiley, Hoboken.

MIT CR (2006), Koncepce rozvoje malého a středního podnikání na období 2007-2013 [Strategy of SME Development for the period 2007-2013], Ministry of Industry and Trade of the Czech Republic, Prague.

MIT CR, List of Beneficiaries - Programmes Progres, Start, Záruka [DVD], Ministry of Industry and Trade of the Czech Republic, Prague.

MRD CR (2006), Strategie regionálního rozvoje České republiky na roky 2007-2013 [Strategy of Regional Development of the Czech Republic for the Years 2007-2013], Ministry of Regional Development of the Czech Republic, Prague.

MRD CR (2007), Národní strategický referenční rámec ČR 2007-2013 [National

Strategic Reference Framework of the Czech Republic 2007-2013], Ministry of Regional Development of the Czech Republic, Prague.

MRD CR (2017), List of Beneficiaries for the Programming Period 2007-2013, Ministry of Regional Development of the Czech Republic, Prague, Retrieved from: www.dotaceeu.cz.

NOVOSÁK J., HÁJEK O., SMÉKALOVÁ L., NEKOLOVÁ J., ŠKARKA M. (2015), Territorial cohesion and the geography of EU cohesion policy funding in the Czech Republic, Transformations in Business \& Economics 14 (3C), 419-432.

POPESCU A. S. (2015), The absorption capacity of European funds - concepts, Annals of the „Constantin Brâncuşi” University of Târgu Jiu, Economy Series 18 (3), 119-125. QIAN H., ACS Z. J., STOUGH R. R. (2013), Regional systems of entrepreneurship: the nexus of human capital, knowledge and new firm formation, Journal of Economic Geography $13(4), 559-587$

SCHRAFF D. (2014), Buying turnout or rewarding loyalists? Electoral mobilization and

EU structural funding in the German Länder, European Union Politics 15 (2), 277-288.

SERVILLO L. (2010), Territorial cohesion discourses: hegemonic strategic concepts in European spatial planning, Planning Theory \& Practice 11 (3), 397-416.

SMALLBONE D., BALDOCK R., NORTH D. (2003), Policy support for small firms in rural areas: the English experience, Environment and Planning C: Politics and Space 21 (6), 825-841.

STAM E. (2005), The geography of gazelles in the Netherlands, Tijdschrift voor economische en sociale geografie 96 (1), 121-127.

TABACHNICK B. G., FIDELL L. S. (2007), Using Multivariate Statistics, Pearson Education, Boston. 
TATAR M. (2010), Estonian local government absorption capacity of European Union structural funds, Administrative Culture 11 (2), 202-226.

VEGA A., CHIASSON M. (2015), Towards a comprehensive framework for the evaluation of small and medium enterprise policy, Evaluation 21 (3), 359-375.

WANG S.-W. (2006), Determinants of new firm formation in Taiwan, Small Business Economics 27 (4-5), 313-321.

Initial submission: 26.05 .2017

Revised submission: 24.10.2017

Final acceptance: 04.12.2017

Correspondence: Faculty of Management and Economics, Tomas Bata University in Zlin, Mostní 5139, 76001 Zlin, Czech Republic.

Email: novosak@fame.utb.cz 
